\title{
Analisis kelayakan usaha pukat pantai
}

\author{
Analysis of feasibility of business on beach seine
}

ROBI Y. DASFORDATE, LEFRAND MANOPPO dan META S. SOMPIE

Progam studi Pemanfaatan Sumberdaya Perikanan, Fakultas Perikanan dan Ilmu Kelautan

Universitas Sam Ratulangi Manado, 95115

\begin{abstract}
Fisheries business are all the efforts of individuals or company to catch fish, to culture fish, including all activities to storing to preserve fish for commercial purposes. business feasibility is related to the financial aspects invested in spending, the revenue and income of an efforts. This study aims to know the business feasibility of beach seines and to know the production sharing system between the owner and labors in one trip fishing. The investment of beach seine business is Rp. 108,864,000. a fixed cost. Rp. 11,889,200. the variable cost is Rp. 33,200,000. the total cost is Rp. 45,089,200. the value of income production is Rp. 137,500,000, BCR (Benefit cost ratio) is 3.05\%. BEP (Break even point) is Rp. 15,664. Rentability is $85 \%$ and the period returning time is 1.177 years or approximately 1 year 2 months. From the results beach seine business in Kelurahan Mawali is visible.
\end{abstract}

Keywords: beach seine, analysis of feasibility, mawali.

\section{ABSTRAK}

Usaha perikanan adalah seluruh usaha perorangan atau badan hukum untuk menangkap ikan, membudidayakan ikan, serta termasuk kegiatan menyimpan mendinginkan atau mengawetkan ikan untuk tujuan komersial. Aspek kelayakan usaha adalah aspek menyangkut masalah keuangan yang diinvestasikan dalam pengeluaran, penerimaan serta pendapatan suatu usaha. Penelitian ini bertujuan mengetahui kelayakan usaha soma dampar dan mengetahui sistem bagi hasil antara pemilik alat tangkap pukat pantai dan buruh pada satu trip penangkapan yang telah dilakukan terhadap satu unit soma dampar Kelurahan Mawali.Penelitian ini menggunakan metode survei dan studi kasus. Investasi sebesar Rp. 108.846.000. biaya tetap Rp. 11.889.200. biaya tidak tetap Rp. 33.200.000. biaya total Rp.45.089.200. pendaptan nilai produksi Rp. 137.500.000. BCR (Benefit Cost Ratio) Sebesar 3.05\%. BEP (Break Even Point) sebesar Rp.15,664. rentabilitas 85\% dan jangka waktu pengembalian dalam waktu 1,177 tahun tahun atau kurang lebih 1 tahun 2 bulan. Maka dari hasil tersebut, usaha soma dampar kelurahan Mawali layak menguntungkan.

Kata-kata kunci: pukat pantai, analisisis kelayakan usaha, mawali

\section{PENDAHULUAN}

Nikijuluw (2002) mengemukakan bahwa pembangunan perikanan terus dikembangkan dan lebih diarahkan pada upaya peningkatan pendapatan nelayan.

Pengelolahan perikanan tangkap dilakukan berdasarkan asas pemanfaatan sumber daya ikan secara rasional dan optimal (Baskoro, 2006).

\footnotetext{
*Penulis untuk penyuratan; email: dasfrobi@gmail.com
}

Salah satu faktor yang mempengaruhi usaha penangkapan ikan adalah konstruksi alat penangkapan ikan yang cocok didukung oleh ketrampilan orang-orang yang menggunakan alat tangkap tersebut (Sadhori, 1984). Untuk itu perlu pengenalan yang lebih banyak tentang desain dan konstruksi alat tangkap.

Beberapa kelurahan disekitar Selat Lembeh yang menggunakan soma dampar atau pukat pantai (beach seine) antara lain: Kelurahan Mawali, 
Binuang, Batu Kota dan Kareko. Hal ini karena usaha alat tangkap soma dampar masih sangat menjanjikan untuk dikembangkan serta mendukung program pemerintah saat ini mulai terfokus dibidang perikanan dan kelautan.

Sudirman dan Mallawa (2000) menyatakan, soma dampar atau pukat pantai (beach seine) karena pengoperasiannya hanya terbatas di tepi pantai. Sekarang ini penggunaan alat tersebut menurun jumlahnya. Alat ini merupakan salah satu jenis pukat kantong yang digunakan untuk menangkap ikan, baik pelagis maupun ikan demersal yang berada di tepi pantai. Pembuatan soma dampar (beach seine) di Kelurahan Mawali Kota Bitung umumnya dilakukan oleh nelayan sendiri berdasarkan pengalaman turun temurun.

Untuk itu penulis tertarik untuk meneliti tentang alat tangkap soma dampar di Kelurahan Mawali dengan tujuan untuk menganalis kelayakan usaha soma dampar.

\section{METODE PENELITIAN}

Lokasi penelitian dilaksanakan di perairan Selat Lembeh Kelurahan Mawali Kecamatan Lembeh Utara Kota Bitung. Pengambilan data dilaksanakan pada bulan Oktober sampai dengan November 2017

Penelitian bersifat deskritif didasarkan pada studi kasus, yang dilakukan dengan cara mempelajari suatu kasus secara intensif dan mendalam pada suatu subyek terbatas (Surahkmad, 1982). Adapun kasus yang menjadi obyek penelitian ini yaitu, usaha penangkapan ikan dengan alat tangkap soma dampar atau pukat pantai.

1 unit Soma dampar yang dioperasikan dengan 2 unit perahu digunakan sebagai sampel dalam penelitian ini. Kelayakan usaha soma dampar dianalisis dengan memakai beberapa parameter yakni biaya investasi, biaya tetap dan biaya tidak tetap kemudian dianalisis pendapatan dan nilai produksi berdasarkan analisis finansial yang dikemukakan oleh Soetrisno (1983), sebagai berikut:

Operating profit $=\mathrm{Tr}-\mathrm{Vc}$

Total cost $/$ total biaya $(\mathrm{Tc})=\mathrm{FC}+\mathrm{Vc}$

Keuntungan absolut $(\pi)=\operatorname{Tr}-\mathrm{Tc}$

Benefit Cost Ratio $(B C R)=\frac{\mathrm{Tr}}{\mathrm{Tc}} \%$
Rentabilitas $=\frac{\pi}{\mathrm{I}} \times 100 \%$

Jangka waktu pengembalian $=\frac{\mathrm{I}}{\pi} \times 1$ tahun

Break Event Point $(B E P)=\frac{\mathrm{Fc}}{1-\left(\frac{\mathrm{Vc}}{\mathrm{Tr}}\right)}$

Dimana :

$\operatorname{Tr}=$ Total pendapatan (total revenue)

$\mathrm{Tc} \quad=$ Total biaya (total cost)

$\pi=$ Keuntungan (profit)

$\mathrm{Fc}=$ Biaya tetap (fixed cost)

$\mathrm{Vc}=$ Biaya tidak tetap (variabel cost)

$\mathrm{I}=$ Investas

\section{HASIL}

Menurut Sunariyah (2004) proyek invstasi merupakan suatu rencana untuk menginvestasikan sumberdaya. Saat itu salah satu usaha soma dampar yang masih aktif beroperasi di Kelurahan Mawali dimiliki oleh 8 keluarga dengan modal usaha investasi yang digunakan untuk menjalankan usaha tersebut seperti tercantum dalam Tabel 1.

Tabel 1. Modal investasi nelayan kelurahan Mawali

\begin{tabular}{rlr}
\hline No. & Investasi Usaha Soma Dampar & \multicolumn{1}{c}{ Harga (Rp) } \\
\hline 1 & Mesin Tempel 15 PK (1 unit) & 21.000 .000 \\
2 & Ketinting RYU 6.5 PK (1 unit) & 1.800 .000 \\
3 & Generator Noqiwa 1500 watt & 2.000 .000 \\
4 & Lampu Kuaci 20 watt (14 buah) & 546.000 \\
5 & Perahu Lampu (1 unit) londe & 6.000 .000 \\
6 & Perahu Soma (1 unit) pelang & 7.500 .000 \\
7 & Soma dampar (1 unit) & 70.000 .000 \\
\multicolumn{2}{c}{ Jumlah } & 108.846 .000 \\
\hline
\end{tabular}

Berdasarkan Tabel 1, besarnya investasi pada usaha satu unit soma dampar sebesar Rp. 108.846.000. Biaya investasi yang dikeluarkan dalam satu periode proses produksi untuk memperoleh berapa kali manfaat secara ekonomis yang dikeluarkan pada awal kegiatan dapat dilihat pada Tabel 2.

Biaya yang tidak berubah ketika aktivitas bisnis meningkat atau menurun, meliputi biaya perawatan dan biaya penyusutan karena jumlahnya relative tetap dan dikeluarkan meski jumlah produksi bertambah atau berkurang Carter (2009).

Biaya penyusutan usaha soma dampar di kelurahan Mawali yang diperoleh pada Tabel 2, berdasarkan pada metode penyusutan saldo menurun (Declining balance Method) yaitu: Penyusutan $=[(100 \%$ : Umur Ekonomis 5 tahun dan 
1 tahun) x 2] x harga beli sedangkan untuk lampu umur ekonomis satu 1 tahun dan biaya perawatan diperoleh dari nelayan soma dampar.

Dalam menjalankan usaha soma dampar memerlukan biaya untuk menunjang kegiatan usaha, diantaranya: biaya pembelian BBM, oli, dan lainya digunakan untuk menunjang kebutuhan kegiatan operasi penangkapan ikan oleh usaha alat tangkap soma dampar. Biaya tersebut termasuk dalam biaya tidak tetap dimana didapatkan hasil total perhari Rp. 166.000, perbulan Rp. 3.320.000, dan pertahun Rp. 33.200.000 (Tabel 3).

Tabel 2. Biaya tetap $(\mathrm{Fc})$

\begin{tabular}{rlrrr}
\hline No & \multicolumn{1}{c}{ Peratalan } & $\begin{array}{c}\text { Penyusutan } \\
\text { (Rp) }\end{array}$ & Perawatan (Rp) & Jumlah (Rp) \\
\hline 1 & Mesin Tempel 15 PK (1 unit) & 2.100 .000 & 150.000 & 2.250 .000 \\
2 & Ketinting 6.5 PK (1 unit) & 180.000 & 150.000 & 330.000 \\
3 & Generator 1500 watt & 200.000 & 150.000 & 350.000 \\
4 & Lampu Kuaci20 watt (14 buah) & 109.200 & 50.000 & 159.200 \\
5 & Perahu Lampu (1 unit) & 600.000 & 150.000 & 750.000 \\
6 & Perahu Soma (1 unit) & 750.000 & 150.000 & 900.000 \\
7 & Soma dampar (1 unit) & 7.000 .000 & 150.000 & 7.150 .000 \\
& $\quad$ Jumlah & 10.939 .200 & 950.000 & 11.889 .200 \\
\hline
\end{tabular}

Tabel 3. Biaya tidak tetap (Vc)

\begin{tabular}{lrrr}
\hline \multicolumn{1}{c}{ Biaya operasional } & Rp/hari $\times 20$ & $\mathrm{Rp} / \mathrm{bulan} \times 10$ & $\mathrm{Rp} /$ tahun \\
\hline BBM dan Oli & 131.000 & 2.620 .000 & 26.200 .000 \\
Biaya takterduga & 35.000 & 700.000 & 7.000 .000 \\
\multicolumn{1}{c}{ Jumlah } & 166.000 & 3.320 .000 & 33.200 .000 \\
\hline
\end{tabular}

Keterangan: dalam 1 bulan $=20$ hari operasi dan 1 tahun $=10$ bulan operasi.

Tabel 4. Total biaya (Tc)

\begin{tabular}{lc}
\hline \multicolumn{1}{c}{ Jenis Biaya } & Rupiah \\
\hline Biaya tetap & 11.889 .200 \\
Biaya tidak tetap & 33.200 .000 \\
Biaya total & 45.089 .200 \\
\hline
\end{tabular}

Biaya total adalah jumlah dari biaya tetap dengan biaya tidak tetap pada usaha soma dampar nelayan kelurahan Mawali adalah Rp. 45.089.200 (Tabel 4).

Ikan hasil pembagian ada yang dijual langsung ke perusahan maupun ke pedagang pengumpul yang ada di wilayah tersebut.Jenis ikan yang dipasarkan yaitu teri (Stolephorus Commersoni) tude (Selaroides sp), deho (Auxis rochii), malalugis (Decapterus $\mathrm{sp}$ ), dalam satu tahun 10 bulan operasi dan dalam satu bulan ada 20 hari operasi. Rata-rata dalam 1 bulan nelayan dapat menangkap ikan sebanyak 55 keranjang, perlu di ketahui bahwa 1 keranjang ikan dengan volume $25 \mathrm{~kg}$, sedangkan harga jual ikan rata-rata adalah Rp. 250.000 per keranjang. Maka dalam satu bulan pendapatan nelayan Tr sebesar Rp.13.750.000, dan pendapatan dalam 1 tahun (10 bulan) Rp.137.500.000/thn.
Nilai yang diperoleh untuk setiap parameter yang dianalisis sebagai berikut:

\section{Operating Profit}

Operating Profit usaha soma dampar yang di jadikan objek pada penelitian sebesar Rp. 104.300.000

\section{Keuntungan absolut ( $\pi$ )}

Keuntungan absolut yang didapat setelah modal dikurangi dengan biaya total, hal ini menunjukan bahwa keuntungan yang diperoleh nelayan sebesar Rp. 92.410 .800

\section{Benefit cost ratio (BCR)}

Benefit cost ration digunakan untuk melihat kelayakan usaha apakah usaha tersebut memberikan keuntungan atau tidak dengan membandingkan pendapatan bersi yang sudah diperoleh dengan biaya yang sudah dikeluarkan, adalah 3,05\%

\section{Break event point (BEP)}

Suatu keadaan dimana usaha yang dilakukan tidak mengalami kerugian ataupun keuntungan, dimana jika $\mathrm{BEP}<1$, usaha tersebut mengalami kerugian, 
jika $B E P=1$, usaha tersebut tidak untung dan tidak rugi, dan jika $B E P>1$, usaha tersebut menguntungkan; $B E P$ yang diperoleh pada usaha soma dampar dalam penelitian ini sebesar 15,664. karena $B E P>1$, maka usaha tersebut menguntungkan. Rentabilitas dan jangka waktu pengembalian. Hasil dari rentabilitas pada usaha soma dampar sebesar $85 \%$. Dari hasil tersebut terlihat jelas keuntungan yang diperoleh sangat besar. Jangka waktu pengembalian modal yang digunakan dalam menjalankan usaha dihitung dari total modal usaha dibagi dengan keuntungan bersih diperoleh hasil sebesar 1,177 tahun atau kurang lebih 1 tahun 2 bulan.

\section{PEMBAHASAN}

Keanekaragaman alat tangkap merupakan salah satu ciri khas dari perikanan tangkap di Indonesia, hal ini disebabkan karena komoditas sumberdaya yang beranekaragaman. Sumberdaya perikanan tropis di Indonesia bersifat gabungan atau multispesies yang berada dalam suatu system ekologi yang kompleks (Zulbainarni, 2011).

Alat tangkap pukat pantai memiliki target tangkapan jenis ikanyang berbeda-beda secara umum alat tangkap ini merupakan kegiatan tangkap skala kecil. Hasil tangkapan utama pada pukat pantai adalah teri (Stolephorus Commersoni) tude (Selaroides sp), deho (Auxisrochii), malalugis (Decapterus sp), dan lainnya, indikasi ini menunjukan bahwa alat tangkap pukat pantai memiliki selektivitas yang rendah. Hal ini disebabkan karena operasi penangkapan bersifat tradisional (Wiyono 2009).

Peraturan menteri perikanan dan kelautan no 2 tahun 2015 tentang larangan alat tangkap ikan, bahwa penggunaan alat penangkapan ikan Pukat Tarik (seinenets) di Wilayah Pengolahaan Perikanan telah mengakibatkan menurunnya sumber daya ikan dan mengancam kelestarian lingkunan sumber daya ikan, sehingga perlu di lakukan pelarangan penggunaan alat penangkap ikan Pukat tarik (seinenets). Namun pada nelayan tersebut memiliki alasan yang kuat untuk terus menggunakan alat tangkap khususnya pukat pantai (beach seine) untuk pengembangan pengolahan perikanan tangkap. Alasan yang di berikan oleh para nelayan setempat untuk terus melakukan kegiatan penangkapan adalah dasar perairan yang berpasir, pendapatan serta lapangan pekerjaan.

Dalam perkembangannya pukat pantai di kota Bitung terus mengalami kemajuan yang baik dan memiliki hasil tangkapan menguntungkan. Dari hasil penelitian ini menunjukan bahwa pendapatan nelayan dalam setahun mencapai hasil yang di peroleh sebesar Rp.137.500.000/thn, Break event point $(B E P)>1$ sebesar 15,664 usaha tersebut menguntungkan dan Benefit cost ratio (BCR) sebesar $3,05 \%$ dikategorikan layak usaha sehingga pantas di pertahankan oleh nelayan setempat untuk terus menggunakan alat tangkap pukat pantai dalam pengelolahan perikanan tangkap.

\section{KESIMPULAN}

Hasil Break event point (BEP) dari usaha soma dampar di Kelurahan Mawali adalah sebesar 15,664. BEP > 1, usaha tersebut menguntungkan. Dan $B C R$ sebesar 3,05\% layak usaha

\section{DAFTAR PUSTAKA}

Baskoro, 2006. Teknologi Perikianan Tangkap yang Bertanggung jawab. Depertemen Pemanfaatan Sumberdaya Perikanan IPB. Bogor. 210 hal.

Carter, W. K. 2009. Akuntansi Biaya "Cost Accounting”. Salemba Empat. Jakarta

Nikijuluw. 2002. Rezim Pengelolahaan Sumberdaya Perikanan, Pustaka Cidensindo Jakarta. 254 hal.

Sadhori, S. N. 1984. Bahan dan Alat Penangkapan Ikan.Yasaguna. Jakarta.

Soetrisno. 1983 Dasar-dasar Evaluasi Proyek Jilid I. Fakultas Ekonomi. UGM. Yogyakarrta

Sunariyah. 2004. Pengantar Pengetahuan Pasar Mo dal. Edisi Kelima. Bandung. CV Alfabeta

Sudirman dan Mallawa. 2000. Teknik Penangkapan Ikan. Rineka Cipta, Jakarta. 168 hal.

Surakhmad. 1982. Metodologi Penelitian Masyarakat. LP3ES. Jakarta.

Wiyono, E. S. 2009. Selektifitas Spesies Alat Tangkap Garuk di Cirebon Jawa Barat. Jurnal Bumi Lestari, 9 (1), pp. 601605.

Zulbainarni, N. Tambunan, M. Syaukat, Y. \& Fahrudin, A. 2011.Model Bioekonomi Eksploitasi Multispesies Sumber Daya Perikanan Pelagis Di Perairan Selat Bali. Marine Fisheries Journal, pp. 141-154. 